\title{
PERTANGGUNGJAWABAN YURIDIS DALAM \\ TRANSAKSI LAYANAN MEDIS (TRANSAKSI TERAPEUTIK) \\ TERMASUK INFORMED CONSENT ATAS \\ TINDAKAN MEDIS PADA RUMAH SAKIT
}

\author{
-Mahadian Tri Ekasari-
}

\begin{abstract}
ABSTRAK
Penelitian ini menghasilkan, Pertama, dengan adanya informed consent tidak semerta-merta tenaga medis/dokter tidak dapat di gugat ataupun dituntut secara hukum, justru dengan adanya informed consent ini pihak tenaga medis/dokter harus bekerja secara profesional dan sesuai dengan standar operasional sebagaimana sudah dituangkan dalam informed consent. Kedua, Rumah sakit sebagai badan hukum (korporasi) dapat dituntut dan dipertanggungjawabkan atas tindakan-tindakan malpraktik tenaga kesehatan di rumah sakit. Pasal 46 Undang-Undang Nomor 44 Tahun 2009 tentang Rumah Sakit bahwa rumah sakit harus bertanggungjawab atas kelalaian yang dilakukan oleh Dokter yang berpraktik di rumah sakit merupakan beban yang ditanggung oleh pemilik dan manajemen rumah sakit. Ketiga, Aada beberapa upaya yang dapat ditempuh dalam hal terjadi kelalaian ataupun malapraktik oleh tenaga kesehatan/dokter/rumah sakit, yakni dengan cara melaporkan kepada MKEK/MKDKI, melakukan mediasi, menggugat secara perdata dan pelaporan secara pidana.
\end{abstract}

Kata Kunci: Informed Consent, Pasien, Rumah Sakit

\begin{abstract}
This research resulted, First, with the informed consent not necessarily the medical staff / doctor cannot be sued or prosecuted, precisely with the existence of this informed consent the medical staff / doctor must work professionally and in accordance with operational standards as stated in informed consent. Second, hospitals as legal entities (corporations) can be prosecuted and accounted for by malpractice actions of health workers in hospitals. Article 46 of Law Number 44 Year 2009 concerning Hospitals that hospitals must be responsible for negligence committed by doctors practicing in hospitals is a burden borne by the owner and management of the hospital. Third, there are several efforts that can be taken in the event of negligence or malpractice by health workers / doctors / hospitals, namely by reporting to the MKEK / MKDKI, conducting mediation, civil litigation and criminal reporting.
\end{abstract}

Keywords: Informed Consent, Patient, Hospital

\section{PENDAHULUAN}

Kesehatan merupakan hal yang sangat penting bagi semua manusia karena tanpa kesehatan yang baik, maka setiap manusia akan sulit dalam melaksanakan aktivitasnya seharihari. Menurut Undang-Undang Nomor 36 Tahun 2009 tentang Kesehatan, kesehatan adalah keadaan sehat, baik secara fisik, mental, spritual maupun sosial yang memungkinkan setiap orang untuk hidup produktif secara sosial dan ekonomis. Dalam Undang-Undang Dasar Negara Republik Indonesia Tahun 1945 (UUD 1945) pada Pasal 28H menetapkan bahwa kesehatan adalah hak bagi setiap individu dan semua warga Negara berhak mendapatkan pelayanan kesehatan.
Untuk mencapai cita-cita dan tujuan tersebut, Negara harus meciptakan kehidupan bangsa yang sejahtera dimana kesehatan merupakan salah satu aspek sejahtera yang cukup penting. Oleh sebab itu dibentuklah berbagai badan pelayanan kesehatan mulai dari tingkat klinik, puskesmas, sampai rumah sakit. Dalam pelayanan kesehatan baik di fasilitas kesehatan tingkat 1 (satu) maupun lanjutan, sangat erat dengan pelaksanaan tindakan medis baik yang bersifat invasive maupun non infasive.

Pemberi layanan kesehatan tersebut biasanya diberikan oleh tenaga medis baik Perawat maupun Dokter. Profesi dokter merupakan profesi yang mempunyai tujuan mulia bagi masyarakat, karena tujuan dasar ilmu 
kedokteran adalah meringankan sakit, penderitaan fisik, psikis, dan sosial pada pasien dan masyarakat. Serta mempertahankan kehidupan insani tanpa memperpanjang proses mati. Sedangkan prinsip dasar etik kedokteran yaitu primum non necere (yang terpenting adalah tidak merugikan sosial maupun ekonomi). Di dalam pelayanan kedokteran, terdapat dua pihak yang saling berhubungan, yaitu dokter dan pasien. Jika tidak tercipta hubungan antara dokter dengan pasien, maka tidak akan terjadi suatu pelayanan kedokteran. Dokter akan berupaya untuk mencapai tujuan dasar dari ilmu kedokteran yang akan diterapkan pada pasien dengan prinsip primum non nocere. Dokter dan pasien merupakan subyek hukum yang mempunyai kewajiban dan hak yang sederajat. Hubungan ini tidak menjanjikan kesembuhan, karena obyek dari hubungan hukum ini adalah upaya dokter berdasar atas kompetensi dan kewenangan dokter untuk menyembuhkan pasien.

Hubungan hukum antara dokter dan pasien yang dilaksanakan dengan rasa kepercayaan dari pasien terhadap dokter disebut dengan istilah transaksi terapeutik. ${ }^{1}$ Transaksi terapeutik tidak hanya berlaku bagi dokter sebagai tenaga medis dan pasien namun berlaku juga bagi tenaga kesehatan dan pasien. Sebagaimana perikatan pada umumnya, pada transaksi terapeutik berlaku ketentuan-ketentuan perikatan sebagaimana diatur dalam Kitab UndangUndang Hukum Perdata. Perikatan dalam transaksi terapeutik terdapat dua pihak, yaitu tenaga kesehatan sebagai pemberi pelayanan medis dan pasien sebagai penerima pelayanan medis.

Semakin berkembangnya masyarakat menyebabkan kesadaran seseorang meningkat akan haknya sebagai konsumen. Sebagai konsumen kesehatan, pasien semakin kritis mencari informasi mengenai kondisi penyakit dan/atau kesehatannya. Tidak jarang dalam suatu tindakan medis pasien merasa bahwa tindakan tersebut semakin memperparah kondisi penyakit dan kesehatannya, sehingga pasien merasa telah terjadi malpraktik atau kesalahankesalahan yang dilakukan oleh tenaga kesehatan atau tenaga medis. Dugaan-dugaan tersebut menyebabkan banyaknya tuntutan yang dilayangkan pasien kepada pihak rumah sakit terhadap kinerja tenaga kesehatan atau tenaga medis yang menanganinya. Padahal tidak selalu kondisi tersebut merupakan malpraktik. Kurangnya pengetahuan pasien sebagai konsumen kesehatan menyebabkan pasien sulit membedakan malpraktik dan risiko medis. Untuk itu diperlukan suatu persetujuan tindakan medis (informed consent) bagi pasien dan tenaga kesehatan.

Berbicara mengenai tindakan medik yang dilakukan oleh dokter, pada dasarnya selalu mengakibatkan dua kemungkinan yaitu berhasil dan tidak berhasil. Ketidak berhasilan seorang dokter dalam melakukan tindakan medik disebabkan oleh dua hal, pertama yang disebabkan oleh overmacht (keadaan memaksa), kedua yang disebabkan karena dokter melakukan tindakan medik yang tidak sesuai dengan standar profesi medik.

Selain itu, yang dapat menimbulkan sengketa antara dokter dengan pasien adalah masalah ketidakpahaman pasien mengenai obyek perjanjian yang dibuatnya dengan dokter. Mereka hanya memahami bahwa, apabila dokter gagal dalam upaya mediknya dalam arti pasien tidak menjadi sembuh atau bahkan meninggal, maka pasien menganggap bahwa dokter tidak memenuhi prestasinya, padahal menurut hukum, hubungan dokter dengan pasien merupakan suatu perjanjian yang obyeknya berupa pelayanan medik atau upaya penyembuhan. Oleh sebab itu keberadaan informed consent dianggap dapat melindungi dokter dari gugatan maupun tuntutan pihak pasien maupun keluarga pasien.

Peraturan Menteri Kesehatan Nomor 290/MenKes/Per/III/2008 menyatakan bahwa persetujuan tindakan medis (informed consent) adalah persetujuan yang diberikan oleh pasien 
atau keluarga terdekat setelah mendapat penjelasan secara lengkap mengenai tindakan kedokteran yang akan dilakukan terhadap pasien. Untuk menyetujui tindakan yang dilakukan tenaga kesehatan, pasien harus diberi penjelasan terlebih dahulu tentang hal-hal yang berhubungan dengan pelayanan yang direncanakan, karena diperlukan suatu keputusan persetujuan. $^{2}$ Dipandang dari kedudukan para pihak, maka informed consent merupakan syarat subjektif untuk terjadinya transaksi terapeutik yang bertumpu pada dua jenis hak asasi yang bersifat hak dasar dari setiap diri manusia, yaitu hak asasi atas informasi dan hak asasi untuk menentukan nasib sendiri. ${ }^{3}$

Mengingat pentingnya pelaksanaan informed consent di Rumah Sakit, maka perlu ditelaah apakah peran pelaksanaan informed consent tersebut sudah berhasil dan memberikan kepuasan kepada pihak medis maupun pasien. Saat ini cukup banyak diberitakan oleh media maupun non media tentang adanya dugaan malpraktik yang dilakukan oleh pekerja medis baik dokter mapun perawat. Akhir-akhir ini sengketa antara dokter dengan pasien sering terjadi, bahkan dari beberapa konflik tersebut meiibatkan rumah sakit sebagai salah satu sarana kesehatan, tempat dokter tersebut mengabdikan diri turut digugat. Beberapa kasus kemudian muncul di media masa, bahkan hal ini seperti halnya puncak gunung es yang kelihatan muncul di permukaan hanya sedikit, padahal kasuskasus yang tidak sampai mencuat ke media masa banyak sekali terjadi.

Sebenarnya sorotan masyarakat terhadap profesi dokter merupakan satu pertanda bahwa saat ini sebagian masyarakat belum puas terhadap pelayanan medis dan pengabdian profesi dokter di masyarakat. Pada umumnya ketidakpuasan para pasien dan keluarga pasien terhadap pelayanan dokter karena harapannya yang tidak dapat dipenuhi oleh para dokter, atau

2 Ida Ayu Sri Kusuma Wardhani, Implementasi Persetujuan Tindakan Kedokteran (Informed Consent) dalam Perjanjian Terapeutik oleh Tenaga Kesehatan terhadap Pasien Rumah Sakit di Provinsi Bali (Jurnal Magister Hukum Udayana, Vol 3 No.1, 2014), hlm. 7 dengan kata lain terdapat kesenjangan antara harapan dan kenyataan yang didapatkan oleh pasien. Oleh sebab itu, peneliti ingin mengetahui seberapa besar pengaruh informed consent terhadap tingkat ketidakpuasan pasien maupun keluarga pasien yang diimplikasikan dalam bentuk gugatan maupun keluhan (complain) kepada pihak Rumah Sakit.

Berdasarkan uraian latar belakang diatas, maka penulis tertarik untuk melakukan penelitian dengan judul "Pertanggungjawaban Yuridis dalam Transaksi Layanan Medis (Transaksi Terapeutik) Termasuk Informed Consent Atas Tindakan Medis Pada Rumah Sakit". Adapun pokok permasalahan yang penulis teliti adalah: Pertama, bagaimanakah pelaksanaan informed consent dalam transaksi terapeutik antara Pasien dan Rumah Sakit. Kedua, bagaimanakah pertanggungjawaban hukum para pihak dalam transaksi terapeutik yang timbul dari informed consent pada pelaksanaan tindakan medis. Ketiga, bagaimanakah seyogyanya pelaksanaan pemberian layanan medik pada suatu transaksi terapeutik yang didalamnya terdapat informed consent.

\section{METODE PENELITIAN}

Dalam melakukan penelitian penulis menggunakan jenis penelitian yuridis normatif, yaitu penelitian yang difokuskan untuk mengkaji penerapan kaidah-kaidah atau norma-norma dalam hukum positif. ${ }^{4}$ Penelitian ini juga menggunakan pendekatan perundang-undangan (statute aproach) dan pendekatan kasus (case aproach). Adapun teknik analisis datanya menggunakan teknik analisis deskriptif kualitatif.

3 H. Muntaha, Hukum Pidana Malpraktik: Pertanggungjawaban dan Penghapus Pidana, (Jakarta: Sinar Grafika, 2017), hlm. 24

${ }^{4}$ Johnny Ibrahim, Teori dan Metodologi Penelitian Hukum Normatif (Malang: Bayumedia Publishing, 2006), hlm. 295 
HASIL DAN PEMBAHASAN

Pelaksanaan Informed Consent dalam Transaksi Terapeutik Antara Pasien dan Rumah Sakit

\section{Perjanjian Terapeutik Sebagai Salah Satu Bentuk Perjanjian}

Perjanjian terapeutik adalah perjanjian antara dokter dengan pasien yang memberikan kewenangan kepada dokter untuk melakukan kegiatan memberikan pelayanan kesehatan kepada pasien berdasarkan keahlian dan keterampilan yang dimiliki oleh dokter tersebut. Dalam Mukadimah Kode Etik Kedokteran Indonesia yang dilampirkan dalam Keputusan Menteri Kesehatan RI Nomor: 434/Men.Kes/X/1983 tentang Berlakunya Kode Etik Kedokteran Indonesia Bagi Para Dokter di Indonesia, mencantumkan tentang transaksi terapeutik sebagai berikut:

"Transaksi terapeutik adalah hubungan antara dokter dengan pasien dan penderita yang dilakukan dalam suasana saling percaya (konfidensial), serta senantiasa diliputi oleh segala emosi, harapan dan kekhawatiran makhluk insani".

Hubungan hukum dalam transaksi terapeutik timbullah hak dan kewajiban masingmasing pihak, baik bagi pihak pasien maupun pihak dokter. Suatu perjanjian dikatakan sah bila memenuhi persyaratan sebagaimana diatur dalam Pasal 1321 KUHPerdata yang menjelaskan:

"Tiada sepakat yang sah apabila sepakat itu diberikan karena kekhilafan atau diperolehnya dengan paksaan atau penipuan".

Sesuai pasal tersebut di atas dapat disimpulkan bahwa secara yuridis keabsahan suatu perjanjian ditentukan oleh kesepakatan para pihak yang mengikatkan dirinya, dengan tanpa adanya kekhilafan, paksaan ataupun penipuan. Sepakat ini merupakan persetujuan yang dilakukan oleh kedua belah pihak di mana kedua belah pihak mempunyai persesuaian kehendak yang dalam transaksi terapeutik sebagai pihak pasien setuju untuk diobati oleh dokter, dan dokterpun setuju untuk mengobati pasiennya. Agar kesepakatan ini sah menurut hukum, maka di dalam kesepakatan ini para pihak harus sadar (tidak ada kekhilafan) terhadap kesepakatan yang dibuat, tidak boleh ada paksaan dari salah satu pihak, dan tidak boleh ada penipuan didalamnya. Untuk itulah diperlukan adanya Informed Consent atau yang juga dikenal dengan istilah "Persetujuan Tindakan Medik".

Perjanjian terapeutik atau transaksi terapeutik termasuk dalam inspanningverbintenis atau perjanjian upaya, karena dokter tidak mungkin menjanjikan kesembuhan kepada pasien, yang dilakukan dokter adalah melakukan pelayanan kesehatan sebagai upaya untuk menyembuhkan pasien. Dalam melakukan upaya ini, dokter harus melakukan dengan penuh kesungguhan dengan mengerahkan seluruh kemampuan dan keterampilan yang dimilikinya dengan berpedoman kepada standar profesi.

Sementara itu, pasien sebagai pihak lainnya yang menerima pelayanan medis harus juga berdaya upaya maksimal untuk mewujudkan kesembuhan dirinya sebagai hal yang diperjanjikan. Tanpa bantuan pasien, maka upaya dokter tidak akan mencapai hasil yang diharapkan. Pasien yang tidak kooperatif merupakan bentuk contributory negligence yang tidak bisa dipertanggungjawabkan oleh dokter. Jika transaksi terapeutik telah memenuhi syarat sahnya perjanjian, maka semua kewajiban yang timbul mengikat bagi para pihak, baik pihak dokter ataupun pihak pasien.

\section{Informed Consent Sebagai Syarat Terjadinya Kontrak Terapeutik Antara Dokter/Tenaga Kesehatan dengan Pasien}

Hubungan hukum antara dokter/tenaga medis dengan pasien apabila dilihat dari aspek hukum perdata maka hubungan tersebut 
merupakan sebuah hubungan kontraktual. ${ }^{5}$ Hubungan kontraktual antara dokter/tenaga medis ini disebut sebagai kontrak terapeutik. Kontrak terapeutik berbeda dengan hubungan kontraktual pada umumnya yang berlaku di masyarakat karena memiliki sifat dan ciri yang khusus, kekhususan tersebut terletak pada apa yang menjadi objek perjanjiannya atau disebut juga dengan prestasi.

Berdasarakan ketentuan-ketentuan tersebut dapat dipahami bahwa syarat pertama yang harus dipenuhi dalam kontrak terapeutik adalah adanya kesepakatan dari pihak yang mengikatkan diri. Dalam hal ini syarat pertama yang harus dipenuhi ini adalah harus adanya kesepakatan antara dokter/tenaga medis dan pasien sebagai subjek-subjek hukum yang saling mengikatkan diri di dalam kontrak terapeutik. Oleh karena itu, setiap pemenuhan prestasi oleh dokter/tenaga medis dalam bentuk upaya pengobatan terhadap pasien harus terlebih didahului dengan adanya kesepakatan. Pada pembahasan sebelumnya telah dijelaskan bahwa informed consent merupakan suatu kesepakatan/persetujuan pasien atas upaya medis yang akan dilakukan oleh dokter terhadap dirinya, setelah pasien mendapatkan informasi dari dokter mengenai upaya medis yang dapat dilakukan untuk menolong dirinya, disertai informasi mengenai segala resiko yang mungkin terjadi. Dengan demikian, secara logis dapat dipahami bahwa informed consent merupakan syarat pertama yang harus dipenuhi dalam kontrak terapeutik.

Informed consent dalam konteks sebagai kesepakatan dalam kotrak terapeutik ini memiliki sedikit perbedaan dengan bentuk kesepakatan lainnya di dalam hubungan kontraktual pada umumnya. Pada hubungan kontraktual umumnya kesepakatan terjadi apabila para pihak menyetujui hal-hal yang pokok yang diadakan di dalam perjanjian tersebut sehingga apa yang dikehendaki oleh pihak yang satu dikehendaki pula oleh pihak

5 Desriza Ratman, Aspek Hukum Informed Consent dan Rekam Medis dalam Transaksi Terapeutik (Bandung: Keni Media, 2013), hlm. 41 yang lain. Dengan kata lain kesepakatan dalam hubungan kontraktual pada umumnya ditekankan kepada kedua belah pihak. Namun, dalam kontrak terapeutik kesepakatan yang terwujud dalam informed consent ini hanya dititikberatkan kepada kehendak pasien dan bukan berdasarkan kepada kehendak dua pihak, yaitu dokter/tenaga medis dan pasien. Dasarnya adalah karena dalam kontrak terapeutik tidak terjadi negosiasi klausul-klausul perjanjian sebelum kesepakatan terjadi karena peran dokter/tenaga medis hanya memberikan informasi mengenai penyakit yang diderita pasien lalu kemudian memberikan rekomendasi mengenai upaya pengobatan terbaik yang dapat dilakukan untuk menyembuhkan penyakit pasien. Selanjutnya, setelah pasien memahami informasi dan rekomendasi tersebut maka pasien mempunyai hak baik itu untuk menyetujui atau menolak rekomendasi yang telah diberikan oleh dokter/tenaga medis. Hal ini didasarkan kepada pertimbangan secara sosiologis bahwa dokter/tenaga medis memiliki pengetahuan yang lebih tinggi daripada pasien yang awam terhadap ilmu kedokteran sehingga secara hukum pasien dipandang sebagai pihak yang rentan diabaikan hak-haknya. Maka dari itu pemenuhan syarat pertama dalam kontrak terapeutik ini sebenarnya berada sepenuhnya di tangan pasien.

Dalam hukum perjanjian berlaku asas konsensual yang berasal dari kata consensus yang berarti sepakat. Asas konsensual ialah pada dasarnya perjanjian dan perikatan yang timbul sejak tercapainya kesepakatan. ${ }^{6}$ Sepakat mereka yang mengikatkan dirinya dimaksudkan bahwa para pihak yang mengadakan perjanjian itu harus bersepakat. Artinya di dalam kesepakatan tersebut para pihak menyepakati hal-hal yang pokok yang diadakan di dalam perjanjian tersebut. Dengan demikian, apa yang dikehendaki oleh pihak yang satu dikehendaki pula oleh pihak yang lain. Dalam mencapai kesepakatan tersebut kedua pihak harus memenuhi syarat-syarat kebebasan menyatakan

\footnotetext{
${ }^{6}$ Daeng Naja, Contract Drafting (Bandung: PT. Citra Aditya Bakti, 2006), hlm. 17
} 
kehendak, yaitu tidak adanya paksaan, penipuan, dan kekhilafan. ${ }^{7}$

Informed consent sebagai pernyataan kesepakatan oleh pasien dalam kontrak terapeutik ini akan dianggap sah apabila pasien menyatakan kehendaknya secara bebas. Apabila dikaitkan dengan ketetapan dalam Pasal 1321 BW maka kehendak bebas ini diartikan bahwa pasien menyatakan persetujuannya dalam wujud informed consent tersebut tanpa disertai adanya kekhilafan, paksaan, atau penipuan. Kekhilafan terjadi apabila salah satu pihak khilaf tentang hal-hal pokok dari apa yang diperjanjikan atau tentang sifat-sifat yang penting dari barang yang menjadi objek perjanjian, ataupun mengenai orang dengan siap diadakan perjanjian itu. ${ }^{8}$ Dinyatakan dalam Pasal 1322 BW bahwa kekhilafan tidak mengakibatkan batalnya suatu perjanjian selain apabila kekhilafan itu terjadi mengenai hakikat barang yang menjadi pokok perjanjian. Kekhilafan itu menjadi sebab kebatalan, jika kekhilafan itu hanya terjadi mengenai dirinya orang dengan siapa seseorang bermaksud membuat suatu perjanjian, kecuali jika perjanjian itu telah dibuat terutama karena mengingat dirinya orang tersebut.

Telah dinyatakan sebelumnya bahwa hubungan antara dokter/tenaga medis dengan pasien ini didasarkan pada dua hak asasi, yaitu: Hak untuk menentukan nasibnya sendiri (the right to self determination) dan Hak atas informasi (the right to information). Dengan demikian, dalam prosedur pelaksanaan informed consent ini pemberian informasi merupakan unsur penting yang harus didapatkan oleh pasien sebelum ia menentukan apa yang terbaik bagi dirinya. Unsur informasi ini pun tidak hanya sebatas pemberian informasi yang cukup dari dokter/tenaga medis tetapi juga harus disertai pemahaman informasi oleh pasien. Oleh karena itu, penting kiranya agar dokter/tenaga medis memberikan informasi yang cukup sesuai dengan ketentuan yang diatur dalam Undang-

7 Abdul Kadir Muhammad, Hukum Perdata Indonesia (Bandung: PT. Citra Aditya Bakti, 2014), hlm. 299
Undang Praktek Kedokteran dan Permenkes No. 290 Tahun 2008 serta perlu dipastikan pula bahwa pasien memahami informasi yang telah diberikan sebelumnya. Tanpa adanya informasi dan/atau pemahaman pasien terhadap informasi yang diberikan maka sama halnya dengan pasien memberikan persetujuan dengan kekhilafan.

Bentuk cacat kehendak berikutnya adalah paksaan dan penipuan. Paksaan menurut bentuknya ada dua, yaitu paksaan fisik dan paksaan psikis. Paksaan fisik adalah suatu bentuk paksaan yang nyata ditujukan pada jasmani. Sementara itu paksaan psikis yaitu suatu paksaan yang mengarah pada ketentraman batin atau kejiwaan/rohani. Dengan demikian yang dimaksud dengan paksaan ialah kekerasan jasmani atau ancaman mempengaruhi kejiwaan yang menimbulkan ketakutan pada orang lain sehingga dengan sangat terpaksa menyetujui suatu perjanjian. ${ }^{9}$ Sementara itu, cacat kehendak berupa penipuan menurut Pasal 1328 BW terjadi apabila satu pihak dengan sengaja memberikan keterangan-keterangan yang palsu atau tidak benar disertai dengan akal-akal cerdik (tipu muslihat) untuk membujuk pihak lawannya memberikan perijinan. Pihak yang menipu itu bertindak secara aktif untuk menjerumuskan pihak lawannya. ${ }^{10}$

Dalam kaitannya dengan pelaksanaan prosedur informed consent, cacat kehendak paksaan dan penipuan ini dapat saja terjadi dalam kondisi yang bersamaan. Adapun bentuk paksaan yang mungkin untuk terjadi adalah paksaan yang mengarah kepada psikologis pasien yang kemudian kekhawatiran dan ketakutan pada diri pasien. Paksaan semacam ini mungkin saja dilakukan dengan memberikan informasi-informasi menyesatkan (salah) yang kemudian akan membuat pasien menjadi khawatir dan takut akan kondisi kesehatannya. Oleh karena kekahwatiran dan ketakutan yang ditimbulkan oleh informasi yang menyesatkan tersebut maka pasien merasa tidak mempunyai

8 Djaja S.Meliala, Perkembangan Hukum Perdata Tentang Benda Dan Hukum Perikatan (Bandung: Nuansa Aulia, 2015), hlm. 70

${ }^{9}$ Achmad Busro, Op.Cit., hlm. 86

${ }^{10}$ Abdul KadirMuhammad, Op.Cit., hlm. 301 
pilihan lain kecuali menyetujui rekomendasi dokter/tenaga medis tersebut.

\section{Pelaksanaan Informed Consent dalam Transaksi Terapeutik}

Dalam pelaksanaannya, adanya informed consent ini bisa memberikan rasa aman bagi dokter pada saat melakukan tindakan medis pada pasien dan bisa digunakan sebagai pembelaan diri apabila hasil tindakan medis yang dilakukan dokter hasilnya tidak seperti yang diinginkan oleh pasien dan keluarga pasien. Apabila pasien telah memberikan informed consent kepada tenaga kesehatan atau dokter atau rumah sakit, maka kedudukan tenaga kesehatan atau dokter menjadi kuat karena di dalam informed consent tersebut telah disebutkan bahwa apabila tenaga kesehatan atau dokter gagal melaksanakan kewajiban, pasien tidak akan menuntut tenaga kesehatan atau dokter atau rumah sakit yang bersangkutan.

Namun secara yuridis pasien mempunyai hak untuk menggugat tenaga kesehatan atau dokter atau rumah sakit apabila tidak melaksanakan standar profesi dengan baik. ${ }^{11}$

Pada dasarnya hakekat dari informed consent itu sendiri mengandung 2 (dua) unsur esensial, yaitu: ${ }^{12}$

a. Informasi yang diberikan oleh dokter, dan

b. Persetujuan yang diberikan oleh pasien.

Pasal 1 angka 1 Peraturan Menteri Kesehatan Republik Indonesia Nomor 290/MENKES/PER/III/2008 tentang

Persetujuan Tindakan Kedokteran mendefinisikan informed consent atau persetujuan tindakan kedokteran merupakan persetujuan yang diberikan oleh pasien atau keluarga terdekat setelah mendapat penjelasan secara lengkap mengenai tindakan kedokteran

11 Salim H.S. dan Erlies Septiana Nurbani, Perkembangan Hukum Kontrak Innominaat Di Indonesia (Buku Kedua) (jakarta: Sinar Grafika, 2014), hlm. 32

12 Hermin Hadiati Koeswadji, Hukum Kedokteran (Studi Tentang Hubungan Hukum Dalam Mana Dokter Sebagai Salah Satu Pihak) (Bandung: Citra Aditya Bakti, 1998), hlm. 24 atau rumah sakit yang akan dilakukan terhadap pasien. Yang perlu digaris bawahi dari pengertian informed consent ini adalah persetujuan dari pasien baru diberikan apabila pasien sudah mendapat penjelasan dari dokter. Persetujuan tersebut berupa persetujuan secara tegas, yaitu dengan dibuat secara tertulis atau secara diam-diam dari pasien. ${ }^{13}$ Pasien atau keluarga pasien harus mendapatkan informasi yang jelas mengenai tindakan medik yang akan dilakukan oleh dokter. Keharusan mendapat informasi tersebut menjadikan informed consent sebagai hak mutlak bagi pasien dan atau keluarga pasien. Dapat dikatakan dalam hal kesehatan ini ada tiga hak-hak pasien yang harus diperhatikan yaitu hak untuk mendapatkan pelayanan kesehatan (the right to health care), hak untuk mendapatkan informasi (the right to information), dan hak untuk ikut menentukan (the right to determination). ${ }^{14}$

Adanya informed consent yang disepakati oleh pasien atau keluarga pasien, maka menimbulkan kewajiban bagi dokter untuk melakukan tindakan medis sesuai dengan prosedur. Seorang dokter yang tidak melaksanakan kewajibannya yang dalam hal ini melakukan upaya penyembuhan yang tidak sesuai dengan prosedur berakibat adanya pertanggungjawaban yang harus dilakukan oleh dokter. Pertanggungjawaban dokter ini terbagi menjadi dua, yaitu pertanggungjawaban secara perdata dan pidana.

Seorang dokter yang tidak melakukan upaya penyembuhan sesuai dengan prosedur maka dianggap tidak melaksanakan prestasi sebagaimana yang diperjanjikan kepada pasien atau keluarga pasien, sehingga pasien dapat menggugat dokter untuk membayar ganti rugi sebagaimana diatur dalam Pasal 1365 KUHPerdata bahwa tiap perbuatan melanggar hukum, yang membawa kerugian kepada seorang lain, mewajibkan orang yang karena

13 Hendrojono, Batas Pertanggungan Hukum Malpraktik Dokter Dalam Transaksi Terapeutik (Surabaya: Srikandi, 2007), hlm. 119

${ }^{14}$ Jendri Maliangga, Hak Informed Consent Sebagai Hak Pasien Dalam Perlindungan Hak Asasi Manusia, Lex et Societatis, Volume I, Nomor 4, Bulan Agustus, Tahun 2013, hlm. 8 
salahnya menerbitkan kerugian itu, mengganti kerugian tersebut. Unsur-unsur yang harus terpenuhi dalam ketentuan Pasal 1365 KUHPerdata adalah adanya perbuatan melanggar hukum, ada kesalahan dari pelaku, ada kerugian pada korban, dan ada hubungan sebab akibat yaitu hubungan antara kesalahan dari pelaku dan kerugian pada korban. Kesalahannya berupa tenaga kesehatan atau dokter melakukan tindakan yang tidak sesuai dengan yang diperjanjikan, misalnya antara tenaga kesehatan atau dokter dengan pasien telah sepakat untuk melakukan operasi terhadap tumor pada usus buntu, tetapi yang dioperasi adalah usus buntunya, sehingga ini merupakan perbuatan melawan hukum. ${ }^{15}$

Pertanggungjawaban Hukum Para Pihak dalam Transaksi Terapeutik yang Timbul dari Informed Consent Pada Pelaksanaan Tindakan Medis

\section{Perlindungan Hukum atas Hak Pasien}

Mengenai perlindungan hukum terhadap pasien, Undang-undang mengatur parameter perlindungan terhadap pasien melalui dua hal. Pertama, pengaturan kewajiban rumah sakit pada Pasal 29. Pasien dilindungi keselamatannya oleh Undang-undang melalui penetapan kewajiban rumah sakit. Pasal 29 menyebutkan ada 20 (dua puluh) kewajiban rumah sakit terhadap keselamatan pasien yang menjadi standar pelayanan kesehatan. Kewajiban utama rumah sakit adalah melakukan pelayanan kesehatan yang sesuai dengan tersebut, Pasal 43 menyebutkan sebagai berikut:

a. Rumah sakit wajib menerapkan standar keselamatan pasien.

b. Standar keselamatan pasien sebagaimana dimaksud pada ayat (1) dilaksanakan melalui pelaporan insiden, menganalisa, dan menetapkan pemecahan masalah dalam rangka menurunkan angka kejadian yang tidak diharapkan.

\footnotetext{
hlm. 53

16 Zahir Rusyad, Hukum Perlindungan Pasien (Konsep Perlindungan Hukum Terhadap Pasien dalam
}

${ }^{15}$ Salim H.S. dan Erlies Septiana Nurbani, Op. Cit. c. Rumah sakit melaporkan kegiatan sebagaimana dimaksud pada ayat (2) kepada komite yang membidangi keselamatan pasien yang ditetapkan oleh Menteri.

Kedua, melaui pengaturan hak pasien di rumah sakit. Hak pasien di rumah sakit tercantum dalam Pasal 32. Terdapat 19 (sembilan belas) hak pasien yang telah ditetapkan oleh Undang-undang, dan salah satu diantaranya adalah hak pasien untuk menggugat perdata, yaitu Pasal 32 huruf q yang berbunyi "Pasien berhak menggugat dan/atau menuntut rumah sakit apabila rumah sakit diduga memberikan pelayanan yang tidak sesuai dengan standar baik secara perdata maupun pidana".

\section{Malapraktik dalam Hukum}

Malpraktik berasal dari kata malpractice yang menurut The Advanced Learner's Dictionary of Current English sebagai wrondoing (kesalahan) atau neglect of duty (kelalaian). Dalam Kamu Besar Bahasa Indonesia kelalaian berasal dari kata lalai yang berarti "tindakan yang kurang hati, tidak mengindahkan (kewajiban, pekerjaan, dsb), lengah". Dalam kamus hukum edisi lengkap, terjamahan dari culpa (kelalaian) adalah "kekhilafan atau kelalaian yang menimbulkan akibat hukum, dianggap melakukan tindak pidana yang dapat ditindak atau dituntut". Sejalan dengan pengertian itu, Pasal 77 UndangUndang Nomor 36 Tahun 2014 tentang Tenaga Kesehatan menyatakan bahwa setiap penerima layanan kesehatan dapat meminta ganti rugi sesuai dengan ketentuan peraturan perundangundangan. Istilah ini memperlihatkan bahwa Undang-undang telah mengakomodasi masalah malapraktik yaitu adanya kesalahan dan kelalaian. ${ }^{16}$

Berdasarkan ketentuan Undang-Undang Nomor 36 Tahun 2014 tentang Tenaga Kesehatan dan Undang-Undang Nomor 29 Tahun 2004 tentang Praktik Kedokteran di atas,

Pemenuhan Hak Kesehatan Oleh Dokter dan Rumah Sakit) (Malang: Setara Press, 2018), hlm. 82-83 
medical practice atau malapraktik medis menurut teori umum dapat dikategorikan dalam dua konsep, pertama malapraktik dari aspek etika yaitu ada Pasal 32 huruf q Undang-Undang Nomor 44 Tahun 2009 tentang Rumah Sakit, kedua malapraktik dari aspek hukum yaitu Pasal 77 Undang-Undang Nomor 36 Tahun 2014 tentang Tenaga Kesehatan. ${ }^{17}$

Lebih lanjut malapraktik dari aspek hukum ini terdiri atas tiga kategori yang lebih spesifik, yaitu: ${ }^{18}$
a. Malapraktik Pidana (Criminal Malpractice);

b. Malapraktik

Perdata (Civil

c. Malapraktik

Administratif

(Administrative Malpractice).

Malapraktik perdata dapat dikatakan terjadi ketika suatu tindakan malapraktik telah menyebabkan luka ataupun kematian bagi seseorang yang diduga disebabkan oleh kesalahan, kelalaian, maupun pelanggaran aturan hukum oleh dokter/tenaga kesehatan/rumah sakit, dimana tindakan malapraktik tersebut tidak tunduk pada aturanaturan hukum pidana maupun hukum administratif. ${ }^{19}$

Perlu untuk diketahui agar gugatan malpraktik tidak salah arah, dan juga untuk memberikan pemahaman kepada masyarakat bahwa kematian ataupun cacat yang diderita pasien tidak selalu merupakan kelalaian dokter, tetapi juga merupakan resiko yang mungkin dapat terjadi pada tindakan medik yang dilakukan dokter tersebut.

Untuk membedakan antara malpraktik medik dengan resiko medik yaitu adanya unsur kelalaian. Adanya kelalaian ini harus dapat dibuktikan sehingga kelalaian ada hubungannya dengan akibat meninggalnya atau cacatnya pasien. Bila unsur kelalaian ini tidak ada, berarti kematian atau cacatnya pasien bukan sebagai akibat dari adanya malpraktik, tetapi merupakan resiko medik yang mungkin dapat terjadi atau karena perjalanan penyakitnya memang demikian.

\section{Pertanggungjawaban Rumah Sakit Apabila Melakukan Kesalahan}

Rumah Sakit wajib bertanggungjawab atas kesalahan ataupun kelalaian yang dilakukan oleh tenaga medis (tenaga kesehatan ataupun dokter) selama hal tersebut berkaitan dengan pekerjaannya. Sehingga berdasarkan hal tersebut diatas dapat disimpulkan bahwa seharusnya ada pertanggungjawaban yang dilakukan oleh pihak rumah sakit kepada pasien atas kesalahan atau kelalaian yang dilakukan oleh tenaga medis kesehatan maupun dokter yan bekerja di rumah sakit tersebut.

Lebih jelasnya berikut adalah alur pertanggungjawaban rumah sakit dan tenaga kesehatan akibat kesalahan ataupun kelalaian yang penulis uraikan dalam bentuk bagan dibawah ini: 


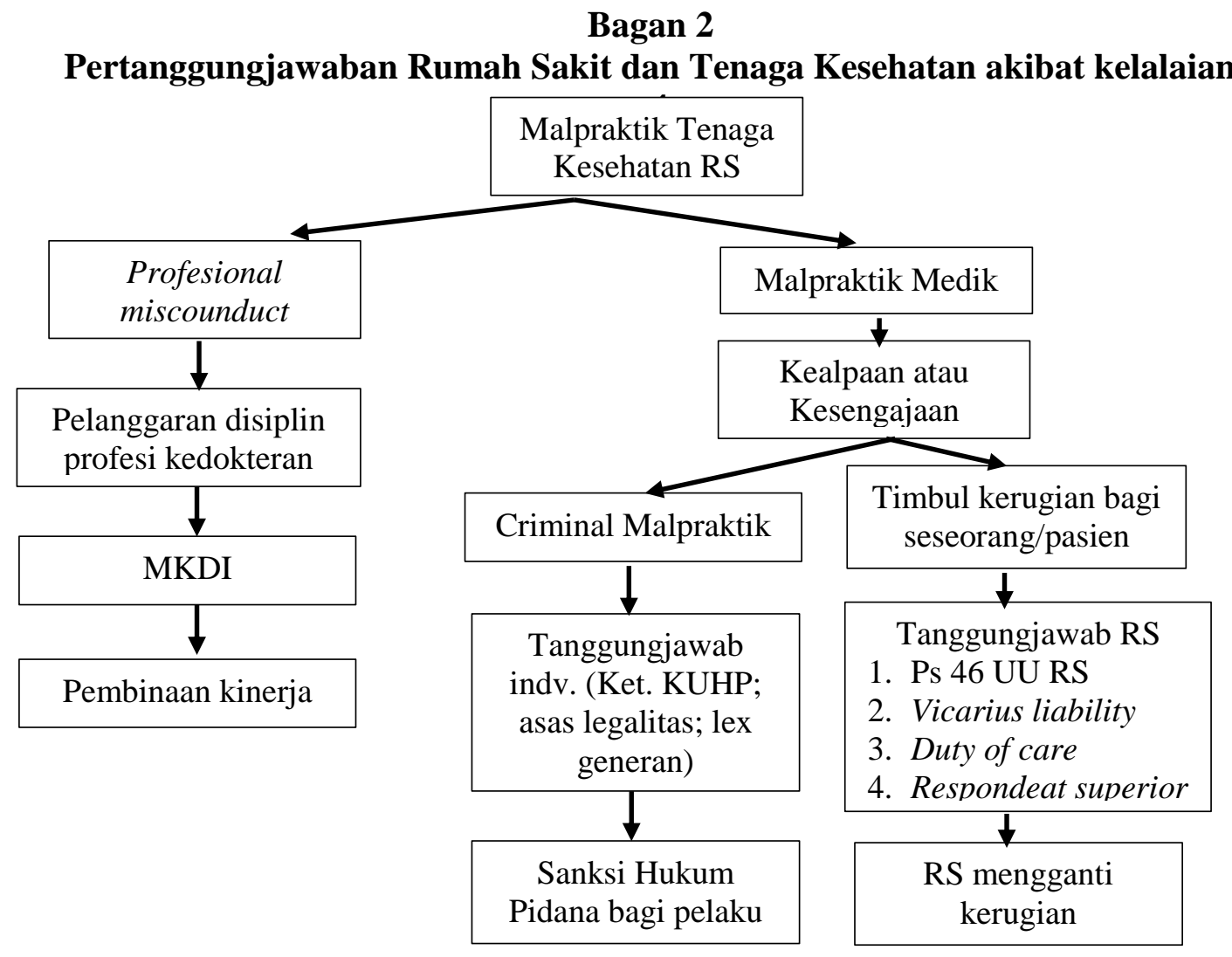

Penjelasan dari bagan tersebut adalah sebagai berikut. Pertama, jika terdapat dugaan malpraktik oleh tenaga kesehatan di rumah sakit, maka disini terdapat indikasi telah terjadi malpraktik medik dan atau terjadi malpraktik profesional dibidang kedokteran. Kedua, terajadi malpraktik kedokteran karena tenaga kesehatan tersebut melanggar etika disiplin profesi kedokteran, dan akan diperiksa oleh Majelis Kehormatan Disiplin Kedokteran. Majelis Kehormatan Disiplin Kedokteran Indonesia akan menjatuhkan sanksi pembinaan kinerja terhadap tenaga kesehetan tersebut.

Ketiga, malpraktik medik yang dilakukan tenaga kesehatan dapat merupakan kealpaan maupun kesengajaan. Jika malpraktik medik ini menimbulkan kerugian, maka pihak rumah sakit akan bertanggungjawab atas kelalaian tenaga kesehatan yang menyababkan kerugian pada seseorang/pasien. Ketentuan bahwa pihak rumah sakit akan bertanggungjawab atas kerugian tersebut diatur dalam Pasal 46 UU Rumah Sakit. Rumah sakit akan bertanggungjawab terhadap tindakan kelalaian tenaga kesehatan, dengan dasar asas vicarious liability, rumah sakit

bertanggungjawab terhadap kualitas perawatan (duty to care). Sesuai dengan doktrin respondeat superior, yang mengandung makna bahwa atasan (rumah sakit) bertanggungjawab atas tindakan-tindakan pelayanan yang menjadi tanggungjawabnya, termasuk tindakan-tindakan yang menyebabkan kerugian bagi orang lain. Keempat, jika malpraktik medik ini sebagai kesengajaan atau kealpaan, yang merupakan pelanggaran hukum pidana, maka tenaga kesehatan tersebut tetap dapat diajukan ke Pengadilan untuk mempertanggungjawabkan atas kelalaian atau kesengajaan tersebut, dan dikenakan sanksi hukum pidana yang berlaku.

Dalam aspek hukum perdata, dasar untuk pertanggungjawaban medik adalah perbuatan melawan hukum (onrechtmatige daad), tenaga kesehatan (tenaga medis ataupun dokter) telah berbuat melawan hukum karena tindakannya bertentangan dengan asas kepatutan, ketelitian serta sikap hati-hati yang diharapkan dari padanya dalam pergaulan dengan sesama warga masyarakat (bertanggungjawab berdasarkan undang-undang). Dalam hal ini yang berlaku adalah Pasal 58 Undang-undang Nomor 36 
Tahun 2009 tentang Kesehatan, Pasal 1401

KUHPerdata mengenai ketentuan perbuatan melanggar hukum.

Pada pertanggungjawaban dalam perbuatan melanggar hukum, unsur kesalahan itu berdiri sendiri. Dilain pihak nampaknya masalah tentang kesalahan dalam perbuatan melanggar hukum, pada kejadian-kejadian tertentu nilainya menjadi kurang penting karena ada kecenderungan unsur kesalahan "dikhayalkan", "diandaikan", dan "diobyektifsir".

Berdasarkan uraian pertanggungjawaban Rumah Sakit di atas, sebenarnya ada beberapa upaya yang dapat ditempuh dalam hal terjadi kelalaian oleh tenaga kesehatan yakni dengan cara melaporkan kepada MKEK/MKDKI, melakukan mediasi, menggugat secara perdata dan pelaporan secara pidana.

Berdasarkan uraian diatas, maka dapat disimpulkan bahwa pasien/keluarga pasien dapat melakukan upaya hukum baik pidana maupun perdata terhadap kesalahan tindakan medis yang dilakukan oleh Dokter/Tenaga Medis ataupun Rumah Sakit. Dan Rumah Sakit bertanggungjawab atas kelalaian ataupun kesalahan yang dilakukan oleh Dokter yang bertugas dalam Rumah Sakit tersebut.

\section{Seyogyanya Pelaksanaan Pemberian Layanan Medik Pada Suatu Transaksi Terapeutik yang di Dalamnya Terdapat Informed Consent}

Dalam praktisnya seorang dokter ketika melakukan suatu tindakan ke pasien perlu memberikan informasi mengenai prosedur, tujuan dan dampak tindakan tersebut. Dalam hal ini, dokter dengan keilmuan yang dimilikinya dianggap sebagai narasumber yang memiliki tanggungjawab untuk memberikan semua informasi mengenai tindakan atau prosedur yang diberikan tersebut (informed). Sedangkan, pasien sebagai pemilik sah dari tubuhnya berhak memberikan keputusan apakah menyetujui (consent) atau menolak tindakan tersebut. Siapapun tanpa izin pasien, tidak berhak melakukan tindakan medis pada tubuhnya. Artinya informasi harus diberikan oleh dokter, dan consent-nya diserahkan sepenuhnya kepada pasien.

Selanjutna, bagaimana jika dihadapkan dengan kasus pasien tidak sadar tetapi membutuhkan tindakan darurat (emergency) untuk menyelamatkan nyawa, dalam etika medis (medikolegal) informed consent dapat ditunda karena tindakan penyelamatan jiwa harus didahulukan. Namun informed consent tetap harus dilakukan setelah pasien kembali sadar atau sebaiknya pada saat bersamaan dengan tindakan penyelamatan jiwa tersebut.

\section{Seyogyanya Pelaksanaan informed consent Pada Rumah Sakit Apabila dalam Keadaan Gawat Darurat \\ Dalam praktiknya, informed consent sendiri} haruskah dalam bentuk tertulis, atau ada bentuk lain jika hal tersebut dalam keadaan darurat. Secara sederhana penulis berpendapat bahwa terdapat empat langkah praktis untuk melakukan informed consent, dimulai pada saat dokter memberikan informasi kepada pasien, dan diakhiri sewaktu pasien telah memberikan consent kepada dokter. Empat langkah yang seyogyanya tersebut adalah sebagai berikut:

\section{a. Communication \\ Komunikasi dengan pasien yang} dilakukan adalah yang bisa memberi pencerahan kepada pasien, yang etis dimana tidak melanggar etika-etika medis. Penggunaan bahasa komunikasi pun bertujuan agar pasien dapat memahaminya, sehingga dokter harus menjelaskan dengan bahasa yang dapat dimengerti oleh pasien.

b. Condition

Dalam hal ini dokter secara langsung harus memahami bagaimana kondisi klinis dan kompetensi dari pasien pada saat dokter memberikan informasi tersebut. Jika yang dihadapi pasien dewasa yang sadar dan kompeten, tentu informed consent harus terjadi pada dokter dan pasien. Tetapi untuk pasien anak-anak dan pasien yang tidak kompeten maka consent diberikan pada pihak ketiga, boleh orang tua, wali atau orang yang dikuasakan. Consent diputuskan setelah mereka mendapatkan informasi yang jelas. Sedangkan yang 
dimaksud dengan pasien tidak kompeten menurut hukum secara sederhana yaitu orang yang tidak sadar, keterbelakangan mental, pikun.

\section{c. Clarification}

Dokter juga harus memberikan penjelasan, minimal pasien harus tahu mengapa perlu dilakukan tindakan medis, apa saja komplikasinya, bagaimana prosedur tindakan medis yang akan dilakukan, dan seberapa besar keberhasilannya. Pasien/keluarganya harus mendapatkan masalah-masalah ini dengan jelas. Bila diperlukan, seorang dokter boleh memberikan second opinion pada dokter lain sesuai dengan kompetensi dokter tersebut. Dari hasil klarifikasi ini diharapkan pemahaman pasien/keluarga akan semakin tercerahkan.

\section{d. Mendapatkan Consent dari Pasien/Keluarga \\ Yang terakhir, yang merupakan tujuan} dari informed consent adalah mendapatkan consent dari pasien/keluarga pasien. Dengan pemahaman yang diperoleh setelah mendapatkan klarifikasi, pasien dapat mengambil keputusan untuk mengabulkan tindakan medis. Consent ini harus murni benar-benar terjadi karena kesadaran dari pasien.

Selanjutnya agar dalam pelaksanaan tindakan medis sesuai dengan standar pelayanan yang sudah diatur dalam peraturan perundangundangan, dan agar lebih memberikan perlindungan terhadap pasien maka seyogyanya informed consent harus memiliki standar atau prosedur operasional.

\section{Seyogyanya Aturan Hukum Mengandung Prinsip Kadilan dan \\ Keseimbangan}

Sebagaimana penulis sampaikan di atas, bahwa dalam Pasal 32 huruf q Undang-Undang Nomor 44 Tahun 2009 adalah norma satusatunya yang secara tegas memberikan hak gugat kepada pasien atas layanan medis yang tidak sesuai dengan standar.

Berdasarkan hal tersebut, dibutuhkan reformulasi atas peraturan perundang-undangan pada bidang kesehatan. Sebagaimana pendapat yang dikemukakan oleh Zahir Rusyad yang menyatakan bahwa secara khusus reformulasi Pasal 32 huruf q Undang-Undang Nomor 44 Tahun 2009 tersebut berbunyi: ${ }^{20}$

"Pasien berhak menggugat dan atau menuntut Rumah Sakit apabila Rumah Sakit diduga memberikan pelayanan yang tidak sesuai dengan standar, baik secara perdata maupun pidana".

Adapun formula peraturan perundangundangan ini adalah mengenai: ${ }^{21}$

a. Norma hak pasien untuk menggugat, yaitu pasien berhak untuk menggugat rumah sakit;

b. Norma hak pasien untuk menuntut, yaitu pasien berhak untuk menuntut rumah sakit;

c. Norma mengenai syarat untuk menggugat, yaitu apabila pasien mendapatkan pelayanan yang tidak sesuai standar;

d. Norma mengenai jenis gugatan/tuntutan, yaitu perdata atau pidana.

Selanjutnya, agar pasien mendapatkan keadilan atas tindakan dokter/tenaga kesehatan dalam tindakan medis yang terbukti melakukan kelalaian/kesalahan ataupun malapraktik, maka penulis mengusulkan obyek gugatan tidak terbatas kepada rumah sakit saja, melainkan dokter/tenaga keshatan yang menangani pasien juga dapat di gugat perdata dan di tuntut pidana.

\section{PENUTUP}

Dalam hal tindakan medis yang diberikan oleh tenaga medis pada rumah sakit harus mendapatkan persetujuan dari pasie atau keluarga pasie, oleh karena itu penerapan Informed Consent yang diterapkan oleh rumah sakit harus sesuai dengan standar operasional. 
Penerapan Informed Consent harus dilakukan sebelum melakukan upaya tindakan medis, tak terkecuali dalam hal-hal tertentu seperti pasien gawat darurat yang tidak memerlukan adanya Informed Consent diawal, akan tetapi Informed Consent harus tetap diterapkan sejalan dengan tindakan medis yang diberikan oleh tenaga medis pada rumah sakit.

Secara yuridis pasien mempunyai hak untuk menggugat/menuntut tenaga kesehatan atau dokter atau rumah sakit apabila tidak melaksanakan standar profesi dengan baik. Rumah sakit sebagai badan hukum (korporasi) dapat dituntut dan dipertanggungjawabkan atas tindakan-tindakan malpraktik tenaga kesehatan di rumah sakit. Ketentuan dalam Pasal 46 Undang-Undang Nomor 44 Tahun 2009 tentang Rumah Sakit bahwa rumah sakit harus bertanggungjawab atas kelalaian yang dilakukan oleh dokter yang berpraktik di rumah sakit merupakan beban yang ditanggung oleh pemilik dan manajemen rumah sakit. Rumah Sakit, dengan statusnya sebagai badan hukum, karena diberi kedudukan menurut hukum sebagai "persoon" dan karenanya merupakan "rechtspersoon", maka Rumah Sakit juga terbebani hak dan kewajibannya menurut hukum atas tindakan yang dilakukannya.

Perlu diketahui oleh masyarakat atau pasien adalah tindakan medis (terepeutik) bukanlah ilmu pasti yang dapat dengan mudah ditentukan hasilnya, maka fungsi dari informed consent sendiri sebenarnya untuk memberi pengertian kepada pasien dan keluarga pasien bahwa jasa kesehatan adalah usaha dan ikhtiar, maka sewaktu-waktu bisa mengalami kegagalan, bukan karena adanya malpraktik dan pelanggaran SOP. Agar dalam pelaksanaan tindakan medis sesuai dengan standar pelayanan yang sudah diatur dalam peraturan perundangundangan, dan agar lebih memberikan perlindungan terhadap pasien maka seyogyanya informed consent harus memiliki standar atau prosedur yang didalamnya memuat asas keseimbangan dan keadilan bagi pasien dokter maupun rumah sakit.

\section{DAFTAR PUSTAKA}

Al Purwohadiwardoyo. 1989. Etika Medis, Yogyakarta: Kanisius

H. Muntaha. 2017. Hukum Pidana Malpraktik: Pertanggungjawaban dan Penghapus Pidana, Jakarta: Sinar Grafika

Hendrojono. 2007. Batas Pertanggungan Hukum Malpraktik Dokter Dalam Transaksi Terapeutik, Surabaya: Srikandi

Ibrahim, Johnny. 2006. Teori dan Metodologi Penelitian Hukum Normatif, Malang: Bayumedia Publishing

Koeswadji, Hermin Hadiati. 1998. Hukum Kedokteran (Studi Tentang Hubungan Hukum Dalam Mana Dokter Sebagai Salah Satu Pihak), Bandung: Citra Aditya Bakti

Maliangga, Jendri. 2013. Hak Informed Consent Sebagai Hak Pasien Dalam Perlindungan Hak Asasi Manusia, Lex et Societatis, Volume I, Nomor 4, Bulan Agustus

Meliala, Djaja S. 2015. Perkembangan Hukum Perdata Tentang Benda Dan Hukum Perikatan, Bandung: Nuansa Aulia

Muhammad, Abdul Kadir. 2014. Hukum Perdata Indonesia, Bandung: PT. Citra Aditya Bakti

Naja, Daeng. 2006. Contract Drafting, Bandung: PT. Citra Aditya Bakti

Ratman, Desriza. 2013. Aspek Hukum Informed Consent dan Rekam Medis dalam Transaksi Terapeutik, Bandung: Keni Media

Rusyad, Zahir. 2018. Hukum Perlindungan Pasien (Konsep Perlindungan Hukum Terhadap Pasien dalam Pemenuhan Hak Kesehatan Oleh Dokter dan Rumah Sakit), Malang: Setara Press

Salim H.S. dan Erlies Nurbani, Septiana. 2014. Perkembangan Hukum Kontrak 
Innominaat Di Indonesia (Buku Kedua),

Jakarta: Sinar Grafika

Wardhani, Ida Ayu Sri Kusuma. 2014.

Implementasi Persetujuan Tindakan

Kedokteran (Informed Consent) dalam

Perjanjian Terapeutik oleh Tenaga

Kesehatan terhadap Pasien Rumah Sakit

di Provinsi Bali, Jurnal Magister Hukum

Udayana, Vol 3 No.1 